\title{
Resilience, mental health and urban migrants: a narrative review
}

\begin{tabular}{|r|l|}
\hline Journal: & International Journal of Migration, Health and Social Care \\
\hline Manuscript ID & IJMHSC-04-2019-0048.R2 \\
\hline Manuscript Type: & Academic Paper \\
\hline Keywords: & $\begin{array}{l}\text { Urban migration, Internal migration, LMICs, resilience, mental health, } \\
\text { migrant }\end{array}$ \\
\hline
\end{tabular}

\section{SCHOLARONE \\ Manuscripts}




\section{Resilience, mental health and urban migrants: a narrative review}

\section{Introduction and background}

This review sets out to survey the literature on resilience approaches to mental health for urban/internal migrants in LMICs (Lower Middle Income Countries) and NICs (Newly Industrialised Countries). Such a review appears timely; for while much of the mental health literature around migration seeks to better understand the biological, psychological or environmental risk factors for mental ill-health, there is increasing recognition that focusing on negative risk factors can sometimes obscure awareness of people's assets and resources for positive mental health, and thereby also lead to over-emphasis on expert-based interventions (Becker, Glascoff et al., 2010). For that reason, this paper sets out to investigate findings on what sources and resources for mental health resilience might have been identified thus far among urban migrant communities. This appears to be an untold story and a perhaps surprising lacuna given the increasing attention paid to resilience concepts within the international development field more broadly. Exploration of the mental health resilience of internal migrants thus appears to be both an important and timely topic. This rapid review was conducted by universities from the UK and India as part of the preliminary phase of a collaborative mental research project based in a basti, or slum, in Pune, India (UK Research and Innovation, 2017).

This review is structured as follows. First, the review strategy is outlined. Second, definitions of 'resilience' and findings concerning mental health resilience and internal migrants in LMICs are explored. Third, the contextual relevance to urban migration of recent cross-disciplinary studies in 'neuro-urbanism' and the urban mind to urban migration is outlined; these research themes were encountered while conducting this review and explore, among other things, the distinctive mental health challenges of urban settings. Further 
positive and negative factors for mental health are then explored. Consideration is also given to some recent research undertaken in the Indian context. Finally, several recommendations for future research are suggested.

\section{Literature review strategy}

$\underline{\text { We are aware of the large and differentiated literature about different kinds of mental health }}$ difficulties and distress in LMICs - addressing conditions from psychosis, to drug problems, to mood disorders. Meanwhile, it is appropriate to note that people sometimes receive multiple diagnoses, on different occasions and often from different diagnosticians, and that in some cases this is the norm rather than the exception (Gaderman et al, 2012). In addition to which, in LMICs it's more likely than in OECD countries that people may not, or may not yet, have been in receipt of any mental health care or specialist diagnoses at all. For these reasons, we have cast the net of our literature review widely.

Data sources comprised the results of a literature search of Pubmed, Scopus and Web of Knowledge. The literature search was deliberately wide ranging and multidisciplinary. While there is much quantitative work available, it was felt important that an initial review on this broad topic - mental health resilience in relation to internal migration in LMICs - should include qualitative studies, review studies as well as more conceptual material germane to our question. Given the conceptual richness and diversity of material we sought to examine, and given that relevant resilience and positive mental health texts are not confined to clinical literature, we did not want to restrict the search by adherence to a predetermined protocol, when we did not know what the literature might cover and what material such a protocol might rule out. We feel that avoiding a predetermined protocol, in which procedural rigour might be won at the expense of sensitivity to the source material, makes for a stronger review 
at this stage. The collection and selection of articles for the narrative review took place between January 2018 and May 2018, and studies published up to 2017 were included.

The primary search aim was to find literature on the mental health of internal migrants in LMICs which discussed resilience. The terms 'internal migration' and 'urban migration' are often used interchangeably so both terms were included (Table 1, search term 'P').

Search term 'Q' was used to restrict the results to India and other Lower Middle Income Countries (LMICs). The list of LMICs used in the search was derived from World Bank data (World Bank, 2017). As can be seen from column 'P AND Q' in Table 1, restricting the search to LMICs reduced the number of 'hits' considerably. In order to broaden the search, newly industrialized countries (NICs) were also included (search term ' $R$ '), on the grounds that many of these countries have also experienced significant internal migration and urbanisation in recent decades. There remains some debate, however, as to which countries should be included in the NIC category. The NIC list used here for search term ' $\mathrm{R}$ ' was derived from Guillen (2008). Table 1, column 'P AND (Q OR R)' shows the number of references found for this search and, as can be seen, the inclusion of NICs more than doubled the number of papers satisfying the criteria; ignoring repeats (from papers found in more than one database) this search yielded 125 papers in total.

\section{Table 1. Number of hits for selected search terms and databases search}

\begin{tabular}{lccc}
\hline Database & \multicolumn{2}{c}{ Number of 'hits' with the search terms in abstract, title or keyword } \\
\cline { 2 - 4 } & $\mathrm{P}$ & $\mathrm{P}$ AND Q & $\mathrm{P}$ AND (Q OR R) \\
\hline Pubmed & 73 & 10 & 58 \\
Scopus & 126 & 17 & 93 \\
Web of Knowledge & 108 & 24 & 98 \\
\hline
\end{tabular}

KEY: search terms

P ('mental health' OR 'mental resilience') AND ('internal migrant' OR 'internal migration' OR 'urban migrant' OR 'urban migration')

Q LMIC* OR 'lower middle income countries' OR Kosovo OR 'El Salvador' OR Tunisia OR Samoa OR Armenia OR Mongolia OR 'Sri Lanka' OR Guatemala OR Micronesia OR Philippines OR Indonesia OR Kiribati OR Egypt OR 'Cabo Verde' OR Swaziland OR Vanuatu OR Palestine OR Morocco OR Bolivia OR Nigeria OR Ukraine OR Congo OR Bhutan OR 'Timor Leste' OR Honduras OR 'Papua 
New Guinea' OR Moldova OR Uzbekistan OR Vietnam OR Nicaragua OR Sudan OR 'Solomon Islands' OR Syria OR 'São Tomé and Príncipe' OR Laos OR India OR Zambia OR Ghana OR Pakistan OR 'Côte d'Ivoire' OR 'Ivory Coast' OR Mauritania OR Kenya OR Cameroon OR Lesotho OR Tajikistan OR Bangladesh OR Kyrgyzstan OR Myanmar OR Yemen OR Cambodia OR Djibouti OR Senegal NIC* OR 'newly industrialized countries' OR 'South Africa' OR Mexico OR Brazil OR China OR India OR Indonesia OR Malaysia OR Philippines OR Thailand OR Turkey

To narrow down our list of 125 articles to a more manageable number for full text scrutiny, we scored the abstracts using an approach closely related to our research question concerning resilience and mental health of urban migrants in LMICs - and prioritised papers according to their focus on one or more of the following three relevant themes:

(A) Mental health resilience (and/or other positive mental health factors) for internal migrants $[$ score $=+3]$

(B) identification and/or exploration of research gaps and future research agendas concerning mental health of internal migrants $[$ score $=+2]$

(C) negative mental health factors for internal migrants [score $=+1]$

Abstracts of each paper were examined for the above three features and a score recorded for each, up to a maximum of 6 points (i.e. $1+2+3$ ) as indicated in Table 2 below:

Table 2. Tally chart

\begin{tabular}{ccccc}
\hline Score & & Themes covered & No. of papers \\
\hline 6 & $=3+2+1$ & ALL themes (A, B and C) & 11 \\
5 & $=3+2$ & themes A and B & 1 \\
4 & $=3+1$ & themes A and C & 37 \\
3 & $=3$, or $2+1$ & theme A only OR theme B and C & 7 \\
2 & $=2$ & theme B only & 1 \\
1 & $=1$ & theme C only & 31 \\
0 & & no themes & 27 \\
\hline
\end{tabular}

It was found that 49 papers had abstracts that scored 4 or more in the above tally (see 
Appendix: Table 4) and this was a manageable number for full text examination. The full text of each of these 49 articles was examined in more detail to examineexplore their themes and key findings (apart from four papers for which full text was found to be unavailable). The references of retrieved articles were also scanned for additional relevant material, which yielded useful contextual and conceptual material _ on 'neurourbanism' and the 'urban brain', for example. Meanwhile, broader literature dealing with resilience is less easily captured in a database, so this area relied on background knowledge and hand searching. In addition, several of the co-authors were able to source other relevant supplementary material. For example, two of our co-authors are of Indian parentage, fluent in Indian languages, and with extensive networks and contacts among Indian mental health scholars and clinicians e.g. at the National Institute of Mental Health and Neurosciences, Bangalore and the Tata Institute of Social Sciences, Mumbai. And these contacts yielded further material, particularly on mental health and urban migration in India.

\section{[Diagram 1 here]}

\section{Resilience}

For the purposes of this review 'resilience' is defined, in part, empirically via the various different definitions given in the papers studied.

According to the Oxford English Dictionary, the earliest known use of the term was in the early seventeenth century (Oxford English Dictionary, 2010). The term derives from the Latin 'resilire', meaning 'to leap back'. As Windle notes, dictionary definitions of 'resilient' tend to emphasize two related but slightly different meanings: '1. (of a person) recovering easily and quickly from misfortune or illness; 2. (of an object) capable of regaining its original shape or position after bending or stretching.' Contemporary ideas about resilience 
have drawn from several academic areas including engineering and social-ecological systems theory but the use of resilience concepts in other fields has risen rapidly in recent years. Definitions can differ between disciplines and sometimes within them and many authors acknowledge difficulties in giving a precise definition of resilience (Windle, 2011). According to Lovell et al, the number of scholarly articles discussing 'resilience' increased from roughly zero in 1997 to some 30,000 in 2015.

Resilience ideas have had considerable influence within international development studies, and for two main reasons. First, they can be used across disciplinary, sectoral and institutional boundaries. Second, ideas about resilience appear to offer a 'positive language that speaks to improvement, as opposed to the concept of '-vulnerability' which can carry more negative connotations' (Lovell, Bahadur et al., 2016).

In mental health studies, resilience concepts were largely pioneered within developmental psychology and studies of stress-resistant children (Garmezy, 1985). And while definitions of resilience in healthcare vary, they usually include three key features: a) identification of risks or adversity, b) identification of sources or resources to help offset the effects of that adversity, c) avoiding the effects of the adversity or adapting positively to it. Drawing on these three features, Windle offers the following summary definition of resilience in health contexts:

\footnotetext{
Resilience is the process of effectively negotiating, adapting to, or managing significant sources of stress or trauma. Assets and resources within the individual, their life and environment facilitate this capacity for adaptation and 'bouncing back' in the face of adversity. Across the life course, the experience of resilience will vary. (Windle, 2011)
}

The appearance of resilience as an important concept in health can be viewed as part of a 'paradigm shift from pathological focus to the positive aspect' (Chen, Wang et al., 2016) and 
the growing recognition that focusing too much upon conceptions of pathology can all-toooften lead to an over-reliance on prescriptive expert-driven interventions:

Interventions that are based on the deficit, problems, or pathologies of individuals tend to direct the attention of professionals to only one view of the person ... The emphasis on deficits or what a person is lacking leads to a cycle of focusing only on what needs to be repaired followed by reliance on prescribed resources or assumed solutions...

(Hammond and Zimmerman, 2012).

On the other hand, more positive resilience and strengths-based approaches are more likely to explore the extent to which people and communities might possess capacities, skills, knowledge and potential for self-reliance or to become 'co-producers' of their own support instead of mere passive recipients (Pattoni, 2012).

Windle notes two distinct ways of understanding resilience in health contents. Firstly, the lifespan developmental approach to resilience tends to focus on psychological resources from earlier life and how those can mediate adversity in later life. On the other hand, Ecological Systems Theory appears to offer a very different way of understanding resilience, by suggesting that people need to be understood
in the environments in which they live ... People do not exist in isolation but interact with, and are influenced by, their physical, social and environmental contexts. Thus the functioning of the defining attributes of resilience can be further explained within this theoretical framework. (Windle, 2011)

Windle suggests that any complete account of resilience would need to be informed by both the lifetime development and Ecological Systems Theory perspectives(Windle, 2011)..

In healthcare, resilience can also be explored at different levels- ${ }_{2}$ from the individual to the population level. Considering a public health and whole population perspective, Seaman et al define resilience as 
the capacity for populations to endure, adapt and generate new ways of thinking and functioning in the context of change, uncertainty or adversity ... The resilience perspective offers value to public health through supporting the development of strong communities ... the resilience perspective provides a framework for enabling people and communities to not only bounce back but crucially, thrive beyond crisis. (Seaman, McNeice et al., 2014)

Also writing from a public health perspective, Wulff et al suggest the broader vantage point of community resilience - with its concern for health systems, social connectedness, psychological health, and vulnerable populations - encourages actions that build preparedness while also addressing the underlying social determinants of health. (Wulff, Donato et al., 2015)

Resilience is increasingly explored in relation to those populations $-{ }_{2}$ such as migrants- ${ }_{2}$ who are facing frequent and particular challenges or adversities.

So what factors in particular have been found to influence resilience among migrants? Cheung et al suggest some migrants may actually have improved their resilience through successfully negotiating the often considerable challenges involved in their migration:

more challenges and greater life stress due to migration may not necessarily compromise migrants' mental functioning; instead such experiences may hone their personal growth, allowing them to develop a resilience that manifests as eudaimonic well-being.

The authors posit that such 'migrant resilience' may help explain why some migrant adolescents exhibit greater resilience than other adolescents in their urban destination (Cheung, 2013, Cheung, 2014).

Fang et al note that migrants are often more likely to report higher levels of resilience, hope, self-esteem and life satisfaction if they become well assimilated to the society and culture they arrive at (Fang, Sun et al., 2017).

A number of scales for measuring resilience have been developed. According to Siriwardhana et al, the RS 25 scale was the first. This 25 item scale explores five different 
facets related to resilience: a purposeful life, perseverance, equanimity, self-reliance and "existential aloneness". A shorter 14 item scale, RS 14, was developed subsequently developed-based on the same five characteristics, andwhich is scored on a seven point Likert scale (Siriwardhana, Abas et al., 2015). Meanwhile, Ye et al use the 27 item 'Resilience scale for Chinese adolescents' which explores two aspects of resilience: personal assets, or the individual's ability to cope with adversity $\overline{\%}_{2}$ and social resources, the individual's perceived support from family members and peers. This scale has also been used in several previous studies exploring resilience of children (Ye, Chen et al., 2016).

Although our primary research focus was mental health resilience of internal migrants in LMICs, only 10 of the LMIC studies retrieved from our main literature search explicitly referred to "resilience," alongside one additional article concerning the Indian context. For these papers, Table 3 summarizes the definitions of resilience used in each article and their main findings in relation to resilience. The plurality of definitions of resilience is acknowledged by some; and the conceptualization of resilience as a "protective factor" is common to several papers - from both China and India. Interestingly, one of these studies conducted in a slum in Mumbai, India (Subbaraman, Nolan et al., 2014) - refers to "joy" in relation to the lives and mental health resilience of slum dwellers; "joy" or "delight" was not explicitly mentioned in any of the remaining papers we examined in relation to migrant mental health in LMICs-(Subbaraman, Nolan et al., 2014).

\section{[Table 3 here]}

As 'resilience' concepts become increasingly influential or fashionable they are also attracting increasing critical attention. For example, according to a recent ODI report, potential problems of using resilience concepts in international development work include: 
- Resilience is often defined in different ways, both within and beyond mental health. Is this a strength of resilience or a weakness?

- Some argue resilience concepts lack explicit values and they should thus be treated with caution when used as guiding framework.

- Emphasising resilience can depoliticise by indicating that vulnerable populations confronted by stressors should largely be responsible for their own wellbeing.

- In international development, practitioners considering resilience sometimes find they have to make trade-offs between different groups, locations and timescales. (Tanner, Bahadur et al., 2017)

\begin{abstract}
Although these are criticisms of resilience approaches more broadly, they clearly have relevance to considerations of mental health resilience of vulnerable populations. For example, it could be argued that mental health research exploring the sources or resources of resilience for internal migrants which overlooks - whether deliberately or not - the political dimensions of the situation would appear naïve at the very least, or grievously short-sighted were it to imply urban migrants are wholly responsible for their own wellbeing.
\end{abstract}

Firdaus (2017) notes the scarcity of literature exploring the impact of migration on the mental wellbeing of rural to urban migrants. And Li and Rose observe how

\begin{abstract}
The focus of most conceptual work on migration and mental health from the 1930s to the present has been on transnational migration, yet the mental health consequences for 'internal' migrants - who have made up the greater part of population movements both historically and today - has been less explored (Li and Rose, 2017).
\end{abstract}

The majority of literature on migration and mental health located via our literature search on Scopus, Web of Knowledge, and PubMed related to China. In addition, relatively few of the empirical papers report longitudinal studies which might have yielded more robust insights into causal relations between factors and their impact on mental health (Qiu, Caine et 
al., 2011). More commonly found were cross-sectional studies describing associations between factors and their apparent effects.

\section{Neuro-urbanism and the urban mind}

Li and Rose insist that '[i]nterdisciplinary research involving sociologists, historians, anthropologists, urban geographers, psychiatrists, neuroscientists and others' is needed if we are to understand the mental health challenges of urban migration, particularly given such a high proportion of that migration is to "the rapidly expanding megacities in developing countries such as China, Brazil and India' where relatively little is known about the mental health challenges of such migrations. An example of the kind of collaborative work on urban mental health that Rose and Li propose was the series of international and interdisciplinary workshops on 'the urban brain', hosted in London from 2013. One outcome of these workshops was a call for "conceptually informed empirical studies of the "neuropolis" and a programme of research on mental health, migration and megacities' (Li and Rose, 2017).

Other scholars in the novel field of neurourbanism have expressed similar concerns (Adli, Berger et al., 2017).

Such studies indicating the merits of situlocating mental health research about urban migration within broader cross-disciplinary contexts, sometimes situate urban migration against a broader background of global historical and cultural transformations. Adli et al suggest public mental health practitioners should engage with cross-disciplinary work on neuro-urbanism in order to improve the wellbeing of individuals and communities and to 'strengthen the resilience of' urban migrants and other high-risk individuals. And they insist that 
City life and mental wellbeing are interdependent in many ways. However, this web of interdependencies is far from being sufficiently understood. Urban planners and health providers have so far largely failed to develop strategies coordinating the bidirectional interaction between urban life and mental wellbeing... (Adli, Berger et al., 2017)

While migration scholars often draw attention to the unique aspects of each person's experience and their potentially unique factors for both positive and negative mental health, scholars of the urban mind identify certain stressors and modulators of health that may be common aspects of urban living. Indeed, commentators have long been aware of how urbanization shapes people's minds and their experience:

by the 1980 s, the idea that the physical and political contours of urban space shape the interior world of city dwellers was well established. A thick, multi-stranded literature showed, in many different ways, how the encounters experienced by those who live in urban environments (of many different sorts) actually moulded their interior worlds, leaving durable impressions upon their souls. And this process was well charted at multiple levels, from the ethnographic to the epidemiological. 'The city' had stopped being only a geographical, spatial, political, commercial and economic reality. It had become a psychological and psychiatric phenomenon too. (Fitzgerald, Rose et al., 2016)

In a recent review of the impact of social exclusion on the mental health of urban migrants in China, Rose and Li suggest the need for much more detailed 'close-up, street-level ethnographic data on the daily experience of being a migrant in the mega-city' (Li and Rose, 2017).

Ash Amin's 2006 study of 'the good city', which has been a lasting influence on contemporary scholars of the urban mind, forcefully counters any naïve notions of city life as managed by an enlightened urban elite that attends to the interests of all ... The idea of good urban governance is an illusion not only for all that it cannot capture, but also for its panoptic authoritarianism veiled as stakeholder democracy. 
Amin's work indicates a potential challenge confronting those who might seek to improve mental health for urban migrants. That is,: how are we to avoid complicity in "panoptic authoritarianism veiled as stakeholder democracy' when developing interventions to improve mental health?

Amin's recommendation was to focus on four key aspects of human solidarity: repair, relatedness, rights and 're-enchantment':

Together, they shape state and civic orientations to multiplicity in urban life, by defining access to the basics of existence, attitudes to strangers, rights of presence and expression, and the scale and purpose of the shared commons.

Amin also insists on the need for hopefulness - not in the sense of false promises handed down from on high or as a way of ignoring persistednt inequities and hardship - but borne out of 'an ethic of care that delivers on the ground ... based on the rights of recognition'. For 'vibrant democracy' to be restored to the life of our cities, Amin argues, such hopefulness needs to be shared more widely and fairly (2006)(Amin, 2006).

The growing literature on 'neurourbanism', 'the urban mind' and 'neuropolis' offers several key insights relevant to research into internal migration, mental health and resilience. These include: the need for greater cross-disciplinarity; the need for close up, 'street level' ethnographic research on the daily experience of urban migrants; and the need for a renewed vibrancy in, and 're-enchantment' of, civic life for every citizen.

\section{Additional positive mental health factors highlighted in the literature}

Although resilience is not explicitly mentioned in many of the studies we examined on internal migration in LMICs, several related terms and phraseelogy - as well as factors which might contribute to resilience - $\underline{\text { are }}$ sometimes are-explored. For example, as early as 1981 Beiser and Collomb had pointed out the need to recognize howacknowledge the ways in 
which individual mental health outcomes for urban migrants are inevitably modified by social contingencies, including spiritual or religious influences as well asand 'personal assets which individuals bring with them.' Such assets might include 'skills such as literacy and the ability to integrate elements of the old and new cultures' (Beiser and Collomb, 1981). More recently, Seeberg et al insist that a more capability based, rather than deficit based, approach to the mental health of migrants would have the benefit of being more holistic and more femalecentric (Seeberg and Luo, 2017).

Among the several factors associated with better mental health that Li et al identified wereidentify are: migrating with a partner, higher salary (if in employment), good selfreported health and cordial relations with fellow workers. The migrantsMigrants in their own study did not appear unduly vulnerable to mental health problems; and the authors speculate this might be because of improved opportunities and upward economic mobility after migration, as well as their relatively high 'social capital' (Li, Wang et al., 2007). Other studies have reiterated the relevance of socioeconomic status to the mental health of urban migrants (Cheng, Wang et al., 2017, Zhang, Liu et al., 2015).

In order to improve the mental health of urban migrants, Wen et al suggest imprevements tothat improving working conditions, living environment, neighbourhood amenities and helping families live together can have a significant effect (Wen and Wang, 2009). Li and Wu, drawing on their own case study of a migrant community in Beijing, examined the impact of social networks on health and found theyse can provide a wide range of support, including emotional and spiritual sustenance ( $\mathrm{Li}$ and $\mathrm{Wu}, 2010)$. Other studies have found likewise found that local ties to their host city and trans-local ties to rural home communities can be associated with a protective effect on mental health and help alleviate stress among urban migrants (Cheung, 2013). Wen et al highlight the positive impact of 
neighbourhood social cohesion and satisfaction on health and note the significant importance for good mental health of feeling safe in one's neighbourhood (Wen, Fan et al., 2010).

Hoi et al found an association between a greater sense of belonging and lower rates of reported depression among urban migrants (Hoi, Chen et al., 2015). Exploring a similar theme, Liang explores the role of trust as 'a type of social capital' and found that different types of trust (family, relative, neighbour, friendship, workmate, schoolmate) had different impacts on self-reported quality of life depending on the age of the migrants (Liang, 2015). Li et al found that money earned from employment, the number of friends a person has, and the quality of their neighbour relationships were significant factors in self-reported good health (Li, Meng et al., 2017).

Chen et al explored the role of coping strategies in the mental health of migrants and found that those migrants who are best able to deploy mature coping strategies, such as problem solving rather than self-blaming, tend to be significantly less liable to mental illness (Chen, Li et al., 2012).

Some authors highlight the importance of having realistic expectations prior to migrating and that unrealistic expectations can lead to subsequent mental distress. Wang et al particularly emphasize the need for prior awareness of the discrimination urban migrants may subsequently suffer at their destination (Wang, Li et al., 2010).

While earlier studies exploring positive factors for health and mental health often tended to foreground basic-material factors $\underline{\text { such }}$ as earnings, recent literature has begun to

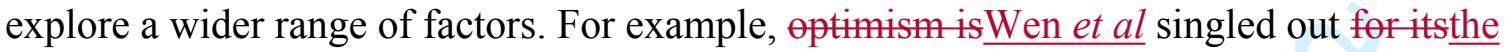
importance by Wen et atof optimism for its association with fewer psychological distress symptoms and the way it seems to reduce the negative mental health impacts of long work hours: 
Optimism taps a person's resilience, hardiness, or a sense of coherence. These psychological traits seem predictive of better health and life outcomes especially among individuals who have suffered extremely traumatic life hardships such as those who survived Nazi concentration camps... Optimistic people tend to see, or believe in, 'light at the end of the tunnel,' and are equipped with greater intra-personal capacity to rebound from crisis. (Wen, Zheng et al., 2017)

One intriguing finding from Li et al was that respondents who consumed alcohol were more likely to report good health: most other previous studies have usually found alcohol consumption to be associated with poor self-reported health (Li, Meng et al., 2017).

\section{Additional negative mental health factors highlighted in the literature}

Many factors understood as impacting negatively on mental health among migrants including loneliness, low socioeconomic status, poor social resources and friendships, separation from family members, and alcohol abuse - are familiar and echoed in the literature surveyed here.

For example, Wen et al found the different levels of psychological distress among internal migrants in two different cities (Shenzen and Shanghai, in China) appeared to be explained, at least partly, by lower earnings and longer working hours in Shenzen (Wen, Zheng et al., 2017).

Lu notes that many of the same stressors which impact on transnational migrants also confront internal migrants, including physical and social changes, stress and feelings of alienation (Lu, 2010a). For Wen et al, loneliness and perceived stress are among the most significant factors associated with negative mental health (Wen, Fan et al., 2010). Firdaus found that adult migrants who were single, widowed, divorced or separated were significantly more likely to suffer from poor mental health (Firdaus, 2017). Meanwhile, for $\mathrm{Hu}$ et al, the most notable stressors on internal migrants included separation from family, separation from familiar surroundings, low social status, high mobility and high risk (Hu, Cook et al., 2008). 
$\mathrm{Li}$ and $\mathrm{Wu}$ highlight the negative effects of having limited social networks ( $\mathrm{Li}$ and $\mathrm{Wu}, 2010)$. Lu reports that the strong evidence of negative psychological impacts of migration were particularly acute for migrants moving alone, supporting the view that separation from family can have a considerable psychological cost (Lu, 2010b).

Wen and Wang highlight the overwhelmingly negative effect of discrimination on mental wellbeing among migrants (Wen and Wang, 2009).

Qiu et al found factors associated with reported depression included self-rated health, economic status, and adaptation to their new environment; meanwhile, social support, length of residence and job satisfaction could also influence depression (Qiu, Caine et al., 2011).

Yang et al found work stress, employmentand working with machinery or transportation to be negatively associated with mental health and wellbeing (Yang, Xu et al., 2012) while Chen et al found unemployment to be a significant risk factor, with the longterm unemployed most at risk of psychiatric symptoms (Chen, Li et al., 2012).

Chen et al discovered that environmental risk factors severely affect migrant mental health and called for efforts to mitigate adverse environmental health effects (Chen, Chen et al., 2013). Zhang et al catalogue the negative mental health impacts of occupational hazards at workin the workplace (Zhang, Liu et al., 2015).

\section{Mental health and migration in Indian context}

A 2013 UNESCO report on migration in India suggests some 326 million, or $28.5 \%$ of the national population, are internal migrants, significantly outnumbering the country's 11.4 million transnational migrants (UNESCO, 2013). Akinola et al point out that if health care as a human right is to be realised in India then it needs to reach all citizens including internal migrants. And to achieve this, future healthcare planning will need to include interventions tailored specifically toward internal migrants (Akinola, Krishna et al., 2014). 
In a 2016 cross-sectional study, Albers et al examined the frequency and severity of depression among internal migrants and found no greater evidence of depressive symptoms than could be found among permanent urban, or rural, residents. They conclude that while migration may often be a risk factor for depression, researchers should always be wary of making over-hasty generalisations, since any particular group of migrants may consist of people-widely diverse in many waysindividuals (Albers, Kinra et al., 2016).

On the other hand, results from a different study, efconducted in a Mumbai slum area, found the severity of common mental disorders reported was greater than had ever been reported in any previous population-based study in India. Mental health stressors identified by the researchers included:
having to sleep sitting up or outside one's home and frequent exposure to rats and insects cause stress in and of themselves, they[and] may also serve as markers of underlying structural deprivation - such as extreme housing density, living next to a solid waste dump, or having a home built of low-quality materials that provide poor barriers against rodents. Also, there is a complex interplay among some stressors, such as income poverty, having a loan, the cost of water, and food security. The qualitative data suggest that the poor experience great stress from trying to decide which basic need (e.g., food or water) should be prioritized, in situations of limited monetary means and sometimes severe debt.

The residents are often all too well aware of the mental health hazards of living in such conditions. As one resident put it:
There is so much tension in this community; I hope you are able to do something about it ... Many people have died because of tension. After all no one will admit that a person in their family died because of tension. It's common for people to silently drink poison or hang themselves. It's a big problem (Subbaraman, Nolan et al., 2014)
A 2016 survey in the Indian Journal of Social Psychiatry notes that problems such 'loneliness, frustration, increased household and social burdening are common among the


migrants' and that factors that can have an impact on theimpacting their mental wellbeing-of

migrants include: age, differences in climate between place of origin and destination, language, food, culture, whether one has migrated alone and whether migration was forced or voluntary. The authors also note how vulnerability to mental health problems appears most acute in the period immediately after arrival but also several years after settling at their destination. Seeking to explain this, the authors suggest many who migrate can be

disheartened by the lack of achievement they had anticipated. This disappointment may result in lower self esteem increasing susceptibility to depression or other psychiatric disorders.

Certain categories appearof people appeared particularly susceptible to mental health problems. These included: women, children, old people, gay, lesbian, bisexual and transgender migrants. And, with some groups-were susceptible to post traumatic stress syndrome. The authors also highlight a relationship between urban dwelling and increased susceptibility to psychosis:

\begin{abstract}
Urbanization is associated with a two-fold increased risk of psychosis. There are speculations that this may be due to loss of social capital and social fragmentation. Rates of schizophrenia and other psychoses are elevated in migrant and minority ethnic populations ... 'Nuclearization' of families and change in family structure may reduce social support for patients with psychosis. (Prasad, Angothu et al., 2016)
\end{abstract}

In a separate study, failure to adjust to the new destination environment was particularly strongly correlated with psychological distress among newly arrived migrants. In order to address this, the authors suggestrecommend training for migrants prior to their migration with the aim of developing 'strategies to adjust with the new urban environment and find strength in their cultural heritage, families, and broader social networks' (Agrawal, Taylor et al., 2015). 
Virupaksha et al note that, while efforts to provide health support for migrants either locally and internationally have often been inadequate, many migrants fail to take up health options even when they are on offer-; this is often because of cultural or language barriers. To address theis problem, these authors suggest the need for trained interpreters and 'culture brokers" and foralongside inclusive and culture specific health interventions (Virupaksha, Kumar et al., 2014).

\section{Recommendations for further investigation}

The literature we surveyed included a range of recommendations for future research including, as noted already, the need for further longitudinal research into risk factors and resilience and other protective factors for mental health (Qiu, Caine et al., 2011) Similarly, Aikins et al point toout the need for longitudinal research to examine strategies for coping and life-transforming strategiestransformation in order to help provide context-specific psychosocial models of support and action (Aikins and Ofori-Atta, 2007). Meanwhile, Ng arguesinsists that effective healthcare planning requires be underpinned by robust data from high quality epidemiological studies $(\mathrm{Ng}, 2010)$.

Firdaus calls for further in-depth research into a) the socioeconomic and environmental problems faced by migrants, but also b) the socioeconomic and environmental problems caused by migrants in order that more comprehensive policy-making might be constructed (Firdaus, 2017).

Chen et al recommend further research on the relationship between individual psychological resilience - measured according to a resilience scale - and other health outcomes (Chen, Wang et al., 2016). Ng notes that while it might be tempting to try to save time and money by trying to extrapolate from existing research in the west and applying it to the Asian context this may be a mistake since migration is a unique process with distinctive 
cultural and political dimensions such that different regions may have very different protective and risk factors for mental health in relation to migration $(\mathrm{Ng}, 2010)$.

As noted above, Li and Rose pointdraw attention to the inadequacy of current social epidemiological research on urban migration and call for more 'close-up, street-level ethnographic data on the daily experience of being a migrant' (Li and Rose, 2017).

\section{Some concluding remarks}

Research into the mental health of internal migrants, as distinct from transnational migrants, appears to have attracted too little attention thus far. And among research that has been undertaken, relatively little attention has been paid to potential resilience or protective factors against mental health risks for migrants.

Nevertheless, there are some signs that things may be changing. Certainly in the Chinese context, a small but growing number of researchers are beginning to explore resilience and other positive aspects of mental health for internal migrants. But, as with much of the broader psychological resilience literature, the common tendency is to assume resilience is best understood as a purely individual- rather than a communal, matter-; or to understand itresilience as a trait, in much the same way that 'character' or 'grit' are often commonly understood. And while such personal capacities should not be underestimated, we have also noted that Ecological Systems Theory reminds us how resilience can be multilayered: relevant to-not only to individual lives but also relevant to, and impacted by, communities and the wider social and environmental contexts.

We suggest further research into the positive mental health capacities and resources for resilience of internal migrants may be appropriate, not least since professional 'expert' mental health provision for internal migrant communities can sometimes be absent or unaffordable. However, we also recognize that an over-reliance on resilience concepts can 
have shortcomings - particularlyif, for example, if they are at the expense of understanding other dimensions of social problems, including the political dimensions. Indeed, researchers exploring resilience among vulnerable groups should be aware of the potential misuses of their work e.g. is there a danger that their work might potentially support or give licence to the idea that vulnerable people are wholly responsible for their own well-being?

The literature of neuro-urbanism suggests common features to the mental health challenges of living in urban environments. To repeat Amin's summary of the urban condition for the vast majority:

cities are polluted, unhealthy, tiring, overwhelming, confusing, alienating. They are the places of low-wage work, insecurity, poor living conditions and dejected isolation for the many at the bottom of social ladder daily sucked into them (Amin, 2006).

Moreover, and echoing sentiments expressed in the recent literature on the urban mind, there is a need for more joined-up cross disciplinary thinking - not only about the mental health challenges and opportunities of vulnerable urban populations, but also about the need for mentally healthy cities. A dialogue between mental health expertise and urban planners is suggested. Such thinking would need to embrace, as the resilience literature suggests, a systems level understanding that includes not only the style of people's interpersonal interactions, but also their interactions with their environments. Indeed, the resilience and

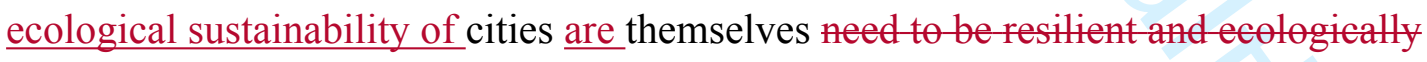
sustainable long-term ifessential aspects of protecting the physical and mental health of theirurban residents is to be likewise protected. (Girardet, 2015, p. 71; Lang \& Rayner, 2012, p. 353).

\section{Appendix} [optional Table 4 here] 


\section{References}

Adli, M., M. Berger, E.-L. Brakemeier, L. Engel, J. Fingerhut, A. Gomez-Carrillo, R. Hehl, A. Heinz, J. Mayer and N. Mehran (2017), "Neurourbanism: towards a new discipline", The Lancet Psychiatry, Vol. 4 No. 3, pp.183-185.

Agrawal, S., F. C. Taylor, K. Moser, G. Narayanan, S. Kinra, D. Prabhakaran, K. S. Reddy, G. Davey Smith and S. Ebrahim (2015), "Associations Between Sociodemographic Characteristics, Pre Migratory and Migratory Factors and Psychological Distress Just After Migration and After Resettlement: The Indian Migration Study", Indian J Soc Psychiatry, Vol. 31 No. 1, pp.55-66. Aikins, A. D.-G. and A. L. Ofori-Atta (2007), "Homelessness and mental health in Ghana - Everyday experiences of Accra's migrant squatters", Journal of Health Psychology, Vol. 12 No. 5, pp.761-778. Akinola, A. B., A. K. I. Krishna and S. K. Chetlapalli (2014), "Health equity for internal migrant labourers in India: an ethical perspective", Indian Journal of Medical Ethics, Vol. 11 No. 4. Albers, H. M., S. Kinra, K. R. Krishna, Y. Ben-Shlomo and H. Kuper (2016), "Prevalence and severity of depressive symptoms in relation to rural-to-urban migration in India: a cross-sectional study", BMC Psychol, Vol. 4 No. 1, p.47.

Amin, A. (2006), "The good city", Urban studies, Vol. 43 No. 5-6, pp.1009-1023.

Becker, C. M., M. A. Glascoff and W. M. Felts (2010), "Salutogenesis 30 Years Later: Where Do We Go from here?", International Electronic Journal of Health Education, Vol. 13, pp.25-32.

Beiser, M. and H. Collomb (1981), "Mastering change. Epidemiological and case studies in Senegal, West Africa", American Journal of Psychiatry, Vol. 138 No. 4, pp.455-459.

Chen, J., S. Chen and P. F. Landry (2013), "Migration, environmental hazards, and health outcomes in China", Soc Sci Med, Vol. 80, pp.85-95.

Chen, L., W. Li, J. He, L. Wu, Z. Yan and W. Tang (2012), "Mental health, duration of unemployment, and coping strategy: a cross-sectional study of unemployed migrant workers in eastern china during the economic crisis", BMC Public Health, Vol. 12 No. 1, p.597.

Chen, X., Y. Wang and Y. Yan (2016), "The Essential Resilience Scale: Instrument Development and Prediction of Perceived Health and Behaviour", Stress and Health, Vol. 32 No. 5, pp.533-542.

Cheng, J., R.-c. Wang, X. Yin, L. Fu and Z.-k. Liu (2017), "U-Shaped Relationship between Years of Residence and Negative Mental Health Outcomes among Rural-to-Urban Children in Migrant Schools in Beijing, China: The Moderating Effects of Socioeconomic Factors", Front Public Health, Vol. 5. Cheung, N. W. T. (2013), "Rural-to-urban migrant adolescents in Guangzhou, China: Psychological health, victimization, and local and trans-local ties", Soc Sci Med, Vol. 93, pp.121-129.

Cheung, N. W. T. (2014), "Social stress, locality of social ties and mental well-being: The case of rural migrant adolescents in urban China", Health Place, Vol. 27, pp.142-154.

Fang, L., R. C. F. Sun and M. Yuen (2017), "Development and preliminary validation of an acculturation scale for China's rural to urban migrant children", International Journal of Intercultural Relations, Vol. 58, pp.1-11.

Firdaus, G. (2017), "Mental well-being of migrants in urban center of India: Analyzing the role of social environment", Indian J Psychiatry, Vol. 59 No. 2, pp.164-169.

Fitzgerald, D., N. Rose and I. Singh (2016), "Living well in the Neuropolis", The Sociological Review Monographs, Vol. 64 No. 1, pp.221-237.

Gadermann, A. M., Alonso, J., Vilagut, G., Zaslavsky, A. M., and Kessler, R. C. (2012) Comorbidity and disease burden in the National Comorbidity Survey Replication (NCS-R). Depression and Anxiety, 29, 9, 41-51.

Garmezy, N. (1985), "Stress resistant children: the search for protective factors", Recent Research in Developmental Psychology, Vol. 4, pp.213-233.

Guillen, M. F. (2008), Limits of Convergence: Princeton University Press.

Hammond, W. and R. Zimmerman (2012), "A strengths-based perspective", A report for resiliency initiatives. 
Hoi, C. K., W. Chen, F. Zhou, K. Sou and B. J. Hall (2015), "The Association between Social Resources and Depressive Symptoms among Chinese Migrants and Non-Migrants Living in Guangzhou, China", Journal of Pacific Rim Psychology, Vol. 9 No. 2, pp.120-129.

$\mathrm{Hu}, \mathrm{X} .$, S. Cook and M. A. Salazar (2008), "Internal migration and health in China", The Lancet, Vol. 372 No. 9651, pp.1717-1719.

Li, C.-C., X.-H. Meng, J.-R. Wang, H.-J. Ma, C. Chen and Y.-Q. Liu (2017), "Association between sociodemographic, psychosocial, lifestyle factors, and self-reported health among migrant laborers in China", Journal of the Chinese Medical Association, Vol. 80 No. 4, pp.204-211.

$\mathrm{Li}$, J. and N. Rose (2017), "Urban social exclusion and mental health of China's rural-urban migrants A review and call for research", Health Place, Vol. 48, pp.20-30.

Li, L., H. M. Wang, X. J. Ye, M. M. Jiang, Q. Y. Lou and T. Hesketh (2007), "The mental health status of Chinese rural-urban migrant workers : comparison with permanent urban and rural dwellers", Soc Psychiatry Psychiatr Epidemiol, Vol. 42 No. 9, pp.716-722.

$\mathrm{Li}, \mathrm{Y}$. and S. Wu (2010), "Social networks and health among rural-urban migrants in China: A channel or a constraint?", Health Promotion International, Vol. 25 No. 3, pp.371-380.

Liang, Y. (2015), "Correlations Between Health-Related Quality of Life and Interpersonal Trust: Comparisons Between Two Generations of Chinese Rural-to-Urban Migrants", Social Indicators Research, Vol. 123 No. 3, pp.677-700.

Lovell, E., A. Bahadur, T. Tanner and H. Morsi (2016), "Resilience: the big picture", Overseas Development Institute.

Lu, Y. (2010a), "Mental health and risk behaviours of rural urban migrants: Longitudinal evidence from Indonesia", Population Studies, Vol. 64 No. 2, pp.147-163.

Lu, Y. (2010b), "Rural-urban migration and health: Evidence from longitudinal data in Indonesia", Soc Sci Med, Vol. 70 No. 3, pp.412-419.

$\mathrm{Ng}$, R. M. K. (2010), "Mental health of migrants in china - is it a no man's land?". Migration and Mental Health. 313-322.

Oxford English Dictionary (2010), "resilience, $n . "$. Third edition ed: Oxford University Press.

Pattoni, L. (2012), Strengths-based approaches for working with individuals, IRISS.

Prasad, K. M., H. Angothu, M. M. Mathews and S. K. Chaturvedi (2016), "How are social changes in the twenty first century relevant to mental health?", Indian J Soc Psychiatry, Vol. 32 No. 3, p.227.

Qiu, P., E. Caine, Y. Yang, Q. Chen, J. Li and X. Ma (2011), "Depression and associated factors in internal migrant workers in China", J Affect Disord, Vol. 134 No. 1-3, pp.198-207.

Seaman, P., V. McNeice, G. Yates and J. McLean (2014), "Resilience for public health: supporting transformation in people and communities", Glasgow Centre for Population Health: Glasgow, UK. Seeberg, V. and S. Luo (2017), "Young Women Rural Migrant Workers in China's West: Benefits of Schooling?", Frontiers of Education in China, Vol. 12 No. 3, pp.332-366.

Siriwardhana, C., M. Abas, S. Siribaddana, A. Sumathipala and R. Stewart (2015), "Dynamics of Resilience in forced migration: A 1-year follow-up study of longitudinal associations with mental health in a conflict-affected, ethnic Muslim population", BMJ Open, Vol. 5 No. 2.

Subbaraman, R., L. Nolan, T. Shitole, K. Sawant, S. Shitole, K. Sood, M. Nanarkar, J. Ghannam, T. S. Betancourt and D. E. Bloom (2014), "The psychological toll of slum living in Mumbai, India: A mixed methods study", Soc Sci Med, Vol. 119, pp.155-169.

Tanner, T., A. Bahadur and M. Moench (2017), "Challenges for resilience policy and practice",

Overseas Development Institute: London, UK, p.25.

UK Research and Innovation. (2017), An exploration of mental health and resilience narratives of migrant workers in India using community theatre methodology [online]: UK Research and Innovation. Available at: https://gtr.ukri.org/projects?ref=AH\%2FR006148\%2F1 [Accessed 24 April 2019].

UNESCO, N. D. O. (2013), "Internal Migration in India Initiative". New Delhi, India, UNICEF, UNESCO.

Virupaksha, H., A. Kumar and B. P. Nirmala (2014), "Migration and mental health: An interface", Journal of natural science, biology, and medicine, Vol. 5 No. 2, p.233.

Wang, B., X. Li, B. Stanton and X. Fang (2010), "The influence of social stigma and discriminatory experience on psychological distress and quality of life among rural-to-urban migrants in China", Soc Sci Med, Vol. 71 No. 1, pp.84-92. 
Wen, M., J. Fan, L. Jin and G. Wang (2010), "Neighborhood effects on health among migrants and natives in Shanghai, China", Health and Place, Vol. 16 No. 3, pp.452-460.

Wen, M. and G. Wang (2009), "Demographic, Psychological, and Social Environmental Factors of Loneliness and Satisfaction among Rural-to-Urban Migrants in Shanghai, China", International Journal of Comparative Sociology, Vol. 50 No. 2, pp.155-182.

Wen, M., Z. Zheng and J. Niu (2017), "Psychological distress of rural-to-urban migrants in two Chinese cities: Shenzhen and Shanghai", Asian Population Studies, Vol. 13 No. 1, pp.5-24.

Windle, G. (2011), "What is resilience? A review and concept analysis", Reviews in Clinical Gerontology, Vol. 21 No. 2, pp.152-169.

World Bank. (2017), World Bank Country and Lending Groups [online]: World Bank. Available at: https://datahelpdesk.worldbank.org/knowledgebase/articles/906519-world-bank-country-and-lendinggroups [Accessed 16 January 2018].

Wulff, K., D. Donato and N. Lurie (2015), "What is health resilience and how can we build it?", Annual review of public health, Vol. 36, pp.361-374.

Yang, T., X. Xu, M. Li, I. R. Rockett, W. Zhu and A. Ellison-Barnes (2012), "Mental health status and related characteristics of Chinese male rural-urban migrant workers", Community Ment Health J, Vol. 48 No. 3, pp.342-351.

Ye, Z., L. Chen, S. E. Harrison, H. Guo, X. Li and D. Lin (2016), "Peer Victimization and Depressive Symptoms Among Rural-to-Urban Migrant Children in China: The Protective Role of Resilience", Frontiers in Psychology, Vol. 7.

Zhang, L., S. Liu, G. Zhang and S. Wu (2015), "Internal migration and the health of the returned population: A nationally representative study of China", BMC Public Health, Vol. 15 No. 1. 
Diagram 1. Flow diagram.

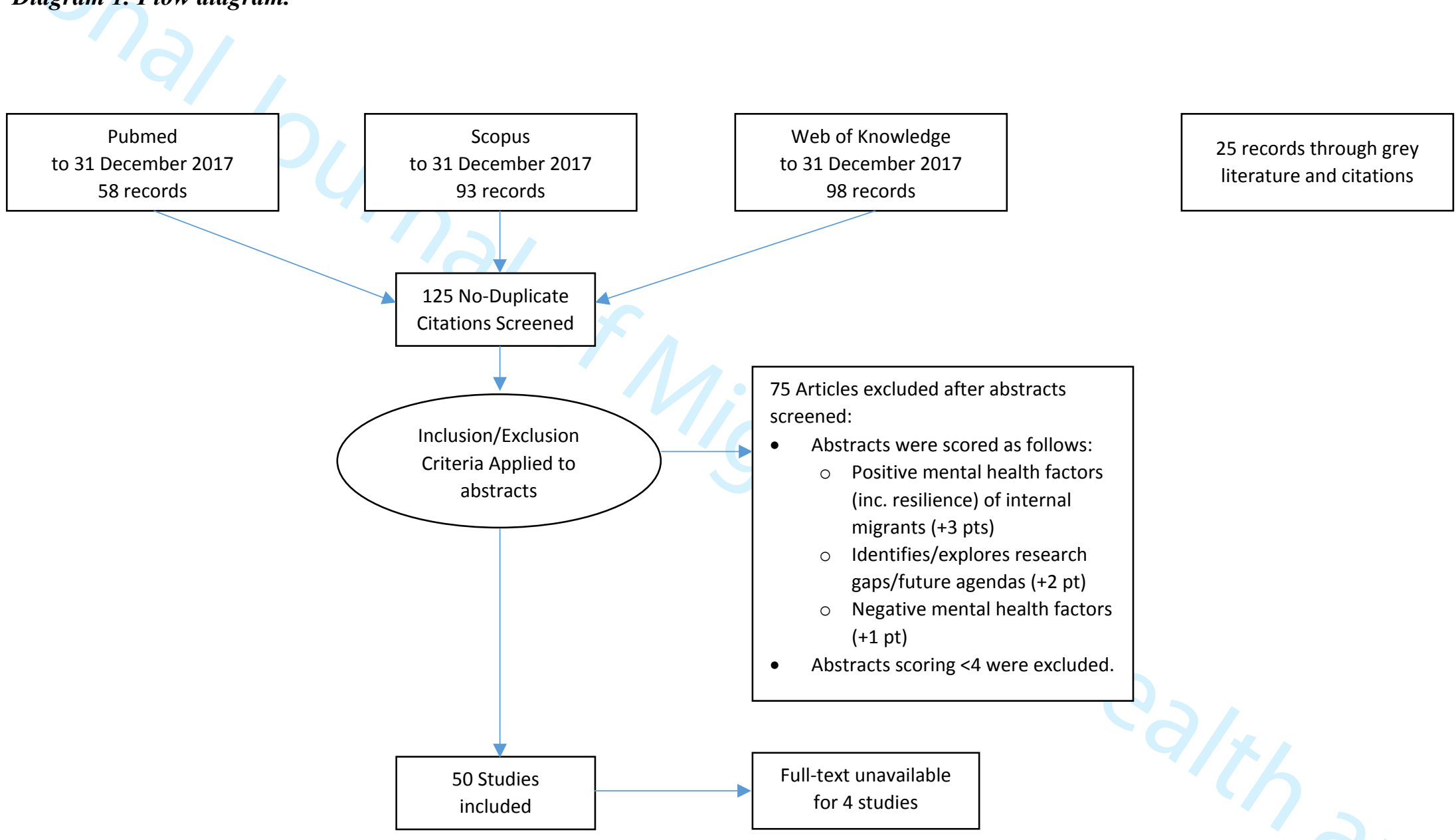

25 records through gre literature and citations 
Please note: this table is an optional addition to the article

\section{Table 3. How mental health resilience is conceptualized in selected studies on internal migration in LMICs}

\begin{tabular}{|c|c|c|c|c|c|}
\hline COUNTRY & AUTHORS & TITLE & $\begin{array}{l}\text { STUDY } \\
\text { TYPE }\end{array}$ & HOW RESILIENCE IS CONCEPTUALIZED & $\begin{array}{l}\text { CONCLUSIONS OR DISCUSSION ABOUT MENTAL } \\
\text { HEALTH RESILIENCE IN RELATION TO } \\
\text { MIGRATION/INTERNAL MIGRATION }\end{array}$ \\
\hline China & $\begin{array}{l}\text { Cheung, N } \\
\text { (2013) }\end{array}$ & $\begin{array}{l}\text { Rural-to-urban migrant } \\
\text { adolescents in Guangzhou, China: } \\
\text { Psychological health, } \\
\text { victimization, and local and } \\
\text { trans-local ties }\end{array}$ & $\begin{array}{l}\text { Cross- } \\
\text { sectional }\end{array}$ & $\begin{array}{ll}- & \text { Resilience = "protective" } \\
- & \text { Resilience may "offset ... social stress" } \\
- & \text { Resilience can manifest as "eudaimonic well- } \\
& \text { being" (p.128) }\end{array}$ & $\begin{array}{l}\text { "A migrant-specific mechanism of protective } \\
\text { resilience" may explain smaller effect of } \\
\text { victimization on migrant adolescents compared } \\
\text { with urban native teenagers. (p.128) }\end{array}$ \\
\hline China & $\begin{array}{l}\text { Fang et al } \\
\text { (2017) }\end{array}$ & $\begin{array}{l}\text { Development and preliminary } \\
\text { validation of an acculturation } \\
\text { scale for China's rural to urban } \\
\text { migrant children }\end{array}$ & $\begin{array}{l}\text { Cross- } \\
\text { sectional }\end{array}$ & & $\begin{array}{l}\text { "Assimilated individuals tend to report high levels } \\
\text { of hope and resilience". (p.2) }\end{array}$ \\
\hline China & $\begin{array}{l}\text { Chen et al } \\
(2016)\end{array}$ & $\begin{array}{l}\text { The Essential Resilience Scale: } \\
\text { Instrument Development } \\
\text { and Prediction of Perceived } \\
\text { Health and Behaviour }\end{array}$ & $\begin{array}{l}\text { Cross- } \\
\text { sectional }\end{array}$ & $\begin{array}{l}\text { - Resilience = "an individual's capability to } \\
\text { anticipate, be flexible with and bounce back } \\
\text { from three types of traumatic and adverse } \\
\text { events (physical, emotional and social)" } \\
\text { (p.533) }\end{array}$ & \\
\hline China & $\begin{array}{l}\text { Cheung, N. } \\
\text { (2014) }\end{array}$ & $\begin{array}{l}\text { Social stress, locality of social ties } \\
\text { and mental well-being: The case } \\
\text { of rural migrant adolescents in } \\
\text { urban China }\end{array}$ & $\begin{array}{l}\text { Cross- } \\
\text { sectional }\end{array}$ & $\begin{array}{ll}\text { - } & \text { Resilience = "protective" against stress } \\
\text { - } & \text { Resilience can manifest as "eudaimonic well- } \\
& \text { being" (p.152) }\end{array}$ & $\begin{array}{l}\text { "The role of migrant resilience in the management } \\
\text { of stressful experiences is worthy of future } \\
\text { inquiry." (p.152) }\end{array}$ \\
\hline China & Ye et al (2016) & $\begin{array}{l}\text { Peer Victimization and Depressive } \\
\text { Symptoms Among Rural-to- } \\
\text { Urban Migrant Children in China: } \\
\text { The Protective Role of Resilience }\end{array}$ & $\begin{array}{l}\text { Cross- } \\
\text { sectional }\end{array}$ & $\begin{array}{l}\text { - 27-item Resilience Scale for Chinese } \\
\text { Adolescents } \\
\text { two subscales: one measures person's } \\
\text { internal capacity to cope; the other assesses } \\
\text { peer and family support. (p.4) }\end{array}$ & $\begin{array}{l}\text { Resilience a protective factor for depressive } \\
\text { symptoms. } \\
\text { Resilience-based interventions to improve } \\
\text { "ability of migrant children to cope with daily } \\
\text { challenges, many negative cognitions, and } \\
\text { maintain hope for the future may be useful in } \\
\text { equipping this population with the "ordinary } \\
\text { magic" of resilience. (p.7) }\end{array}$ \\
\hline
\end{tabular}




\begin{tabular}{|c|c|c|c|c|c|}
\hline China & $\begin{array}{l}\text { Wen et al } \\
\text { (2017) }\end{array}$ & $\begin{array}{l}\text { Psychological distress of rural-to- } \\
\text { urban migrants in two Chinese } \\
\text { cities: Shenzhen and Shanghai }\end{array}$ & $\begin{array}{l}\text { Cross- } \\
\text { sectional }\end{array}$ & $\begin{array}{l}\text { "Optimism taps a person's resilience, } \\
\text { hardiness, or a sense of coherence. These } \\
\text { psychological traits seem predictive of better } \\
\text { health and life outcomes". (p17) }\end{array}$ & \\
\hline China & $\begin{array}{l}\text { Zhuang et al } \\
\text { (2017) }\end{array}$ & $\begin{array}{l}\text { Differential impacts of social } \\
\text { support on mental health: A } \\
\text { comparison study of Chinese } \\
\text { rural-to-urban migrant } \\
\text { adolescents and their urban } \\
\text { counterparts in Beijing, China }\end{array}$ & $\begin{array}{l}\text { Cross- } \\
\text { sectional }\end{array}$ & $\begin{array}{l}\text { - } \quad \text { Resilience = "a dynamic process wherein } \\
\text { individuals display positive adaptation } \\
\text { despite experiences of adversity or trauma." } \\
\text { (p.49) }\end{array}$ & \\
\hline Ghana & $\begin{array}{l}\text { Aikins et al } \\
\text { (2007) }\end{array}$ & $\begin{array}{l}\text { Homelessness and } \\
\text { Mental Health in } \\
\text { Ghana: Everyday Experiences of } \\
\text { Accra's Migrant Squatters }\end{array}$ & $\begin{array}{l}\text { Cross- } \\
\text { sectional }\end{array}$ & - $\quad$ resilience = "psychological strength" & $\begin{array}{l}\text { destitute demonstrated resilience "through } \\
\text { the strategies they adopted to address daily } \\
\text { insecurities. However these strategies were } \\
\text { insufficient to transform their lives in the way they } \\
\text { desired." (p.773) }\end{array}$ \\
\hline India & $\begin{array}{l}\text { Subbaraman } \\
\text { (2014) }\end{array}$ & $\begin{array}{l}\text { The psychological toll of slum } \\
\text { living in Mumbai, India: a mixed } \\
\text { methods study }\end{array}$ & $\begin{array}{l}\text { Mixed } \\
\text { methods } \\
\text { study }\end{array}$ & - $\quad$ Resilience $=$ "protective factors" & $\begin{array}{l}\text { "While this paper sheds light on their tribulations, } \\
\text { it fails to capture the joy and resilience that also } \\
\text { constitute their lived reality." (p.155) }\end{array}$ \\
\hline India & $\begin{array}{l}\text { Virupaksha et } \\
\text { al (2017) }\end{array}$ & $\begin{array}{l}\text { Migration and mental health: An } \\
\text { interface }\end{array}$ & $\begin{array}{l}\text { Review } \\
\text { article }\end{array}$ & & $\begin{array}{l}\text { Evidence suggests children of transnational } \\
\text { migrants have "poor resilience" compared with } \\
\text { children of non-migrant families. (p.236) }\end{array}$ \\
\hline Sri Lanka & $\begin{array}{l}\text { Siriwardhana } \\
\text { et al (2015) }\end{array}$ & $\begin{array}{l}\text { Dynamics of resilience in forced } \\
\text { migration: a 1-year follow-up } \\
\text { study of longitudinal associations } \\
\text { with mental } \\
\text { health in a conflict-affected, } \\
\text { ethnic Muslim population }\end{array}$ & $\begin{array}{l}\text { Cross- } \\
\text { sectional }\end{array}$ & 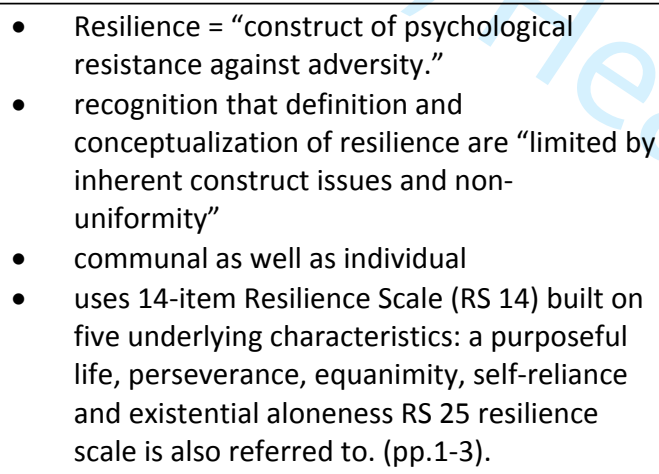 & $\begin{array}{l}\text { "resilience was more strongly and robustly } \\
\text { associated with economic and social factors than } \\
\text { with the presence of mental disorder." (p.1) }\end{array}$ \\
\hline
\end{tabular}




\section{Table 4. Articles selected}

\begin{tabular}{|c|c|c|c|c|c|c|c|c|c|c|c|c|c|}
\hline No. & WHERE? & $\begin{array}{l}\text { is } \\
\text { resilience } \\
\text { referred } \\
\text { to in full } \\
\text { text? }\end{array}$ & YEAR & AUTHORS & TITLE & JOURNAL & STUDY TYPE & $\begin{array}{c}\text { QUANTITATIVE } \\
\quad \\
\text { QUALITATIVE }\end{array}$ & DATA TYPE & $\begin{array}{c}\text { (A) } \\
\text { ve } \\
\text { mental } \\
\text { heatlth } \\
\text { factors? }\end{array}$ & $\begin{array}{c}\text { (B) } \\
\text { identify } \\
\text { research } \\
\text { gaps/ } \\
\text { future } \\
\text { agendas? }\end{array}$ & $\begin{array}{c}\text { (c) } \\
\text {-ve } \\
\text { mental } \\
\text { health } \\
\text { factors? }\end{array}$ & $\begin{array}{c}\text { Tally } \\
\text { score } \\
\text { (eg } \\
3+2+1)\end{array}$ \\
\hline 1 & China (NIC) & No & 2008 & Huet al & Internal migration and health in China & The Lancet & Commentary & & & 3 & 2 & 1 & 6 \\
\hline 2 & China (NIC) & No & 2010 & Wen et al & Neighborhood effects on health among migrants and natives in Shanghai, China & Health \& Place & Cross-sectional & Quantitative & $\begin{array}{l}\text { Secondary } \\
\text { data }\end{array}$ & 3 & 2 & 1 & 6 \\
\hline 3 & China (NIC) & No & 2011 & Qiu et al & Depression and associated factors in internal migrant workers in China & $\begin{array}{l}\text { Journal of Affective } \\
\text { Disorders }\end{array}$ & Cross-sectional & Quantitative & Primary data & 3 & 2 & 1 & 6 \\
\hline 4 & China (NIC) & Yes & 2013 & Cheung, $\mathrm{N}$ & $\begin{array}{l}\text { Rural-to-urban migrant adolescents in Guangzhou, China: Psychological health, } \\
\text { victimization, and local and trans-local ties }\end{array}$ & Social Science \& Medicine & Cross-sectional & Quantitative & Primary data & 3 & 2 & 1 & 6 \\
\hline 5 & China (NIC) & No & 2013 & Mou et al & $\begin{array}{l}\text { Health of Chinas rural-urban migrants and their families: a review of literature } \\
\text { from } 2000 \text { to } 2012\end{array}$ & British Medical Bulletin & $\begin{array}{l}\text { Literature } \\
\text { Review }\end{array}$ & & & 3 & 2 & 1 & 6 \\
\hline 6 & China (NIC) & No & 2015 & Liang et al & $\begin{array}{l}\text { Utilization of Health Services and Health-Related Quality of Life Research of Rural- } \\
\text { to-Urban Migrants in China: A Cross-Sectional Analysis }\end{array}$ & Social Indicators Research & Cross-sectional & Quantitative & $\begin{array}{l}\text { Secondary } \\
\text { data }\end{array}$ & 3 & 2 & 1 & 6 \\
\hline 7 & China (NIC) & No & 2016 & Lin et al & $\begin{array}{l}\text { Association between Social Integration and Health among Internal Migrants in } \\
\text { ZhongShan, China }\end{array}$ & Plos One & Cross-sectional & Quantitative & $\begin{array}{l}\text { Secondary } \\
\text { data }\end{array}$ & 3 & 2 & 1 & 6 \\
\hline 8 & China (NIC) & Yes & 2017 & Fang et al & $\begin{array}{l}\text { Development and preliminary validation of an acculturation scale for China's rural } \\
\text { to urban migrant children }\end{array}$ & $\begin{array}{l}\text { International Journal of } \\
\text { Intercultural Relations }\end{array}$ & $\begin{array}{l}\text { Cross-sectional } \\
\text { (two phase) }\end{array}$ & Quantitative & Primary data & 3 & 2 & 1 & 6 \\
\hline 9 & India (LMIC) & No & 2017 & Firdaus & $\begin{array}{l}\text { Mental well-being of migrants in urban center of India: Analyzing the role of social } \\
\text { environment }\end{array}$ & Indian Journal of Psychiatry & Cross-sectional & Quantitative & Primary data & 3 & 2 & 1 & 6 \\
\hline 10 & China (NIC) & No & 2017 & Liet al & $\begin{array}{l}\text { Association between sociodemographic, psychosocial, lifestyle factors, and self- } \\
\text { reported health among migrant laborers in China }\end{array}$ & $\begin{array}{l}\text { Journal of the Chinese } \\
\text { Medical Association }\end{array}$ & Cross-sectional & Quantitative & $\begin{array}{l}\text { Secondary } \\
\text { data }\end{array}$ & 3 & 2 & 1 & 6 \\
\hline 11 & China (NIC) & $\begin{array}{c}\text { abstract } \\
\text { only }\end{array}$ & 2017 & Seeberg et al & Young Women Rural Migrant Workers in China's West: Benefits of Schooling? & $\begin{array}{l}\text { Frontiers of Education in } \\
\text { China }\end{array}$ & $\begin{array}{l}\text { Longitudinal } \\
\text { (prospective) }\end{array}$ & Quantitative & Primary data & 3 & 2 & 1 & 6 \\
\hline 12 & China (NIC) & Yes & 2016 & Chen et al & $\begin{array}{l}\text { The Essential Resilience Scale: Instrument Development and Prediction of } \\
\text { Perceived Health and Behaviour }\end{array}$ & Stress and Health & Cross-sectional & $\begin{array}{l}\text { Explores } \\
\text { reliability and } \\
\text { validity of scale }\end{array}$ & Primary data & 3 & 2 & & 5 \\
\hline 13 & $\begin{array}{l}\text { Senegal } \\
\text { (LMIC) }\end{array}$ & $\begin{array}{c}\text { abstract } \\
\text { only }\end{array}$ & 1981 & Beiser et al & Mastering change. Epidemiological and case studies in Senegal, West Africa & $\begin{array}{l}\text { American Journal of } \\
\text { Psychiatry }\end{array}$ & & Qualitative & & 3 & & 1 & 4 \\
\hline 14 & Brazil (NIC) & $\begin{array}{c}\text { abstract } \\
\text { only }\end{array}$ & 1982 & $\begin{array}{l}\text { De Almeida- } \\
\mathrm{F}^{\prime}\end{array}$ & Internal migration and mental disorders: new evidence for an old hypothesis & $\begin{array}{l}\text { Acta Psiquiatrica y } \\
\text { Psicologica de America } \\
\text { Latina }\end{array}$ & Cross-sectional & Quantitative & Primary data & 3 & & 1 & 4 \\
\hline 15 & $\begin{array}{l}\text { Ghana } \\
\text { (LMIC) }\end{array}$ & Yes & 2007 & Aikins et al & $\begin{array}{l}\text { Homelessness and mental health in Ghana - Everyday experiences of Accra's } \\
\text { migrant squatters }\end{array}$ & $\begin{array}{l}\text { Journal of Health } \\
\text { Psychology }\end{array}$ & Cross-sectional & Qualitative & Primary data & 3 & & 1 & 4 \\
\hline 16 & China (NIC) & No & 2007 & Liet al & $\begin{array}{l}\text { The mental health status of Chinese rural-urban migrant workers : comparison } \\
\text { with permanent urban and rural dwellers }\end{array}$ & $\begin{array}{l}\text { Soc Psychiatry Psychiatr } \\
\text { Epidemiol }\end{array}$ & Cross-sectional & Quantitative & Primary data & 3 & & 1 & 4 \\
\hline 17 & China (NIC) & No & 2009 & Wen et al & $\begin{array}{l}\text { Demographic, Psychological, and Social Environmental Factors of Loneliness and } \\
\text { Satisfaction among Rural-to-Urban Migrants in Shanghai, China }\end{array}$ & $\begin{array}{l}\text { International Journal of } \\
\text { Comparative Sociology }\end{array}$ & Cross-sectional & Quantitative & $\begin{array}{l}\text { Secondary } \\
\text { data }\end{array}$ & 3 & & 1 & 4 \\
\hline 18 & China (NIC) & No & 2010 & Liet al & $\begin{array}{l}\text { Social networks and health among rural-urban migrants in China: A channel or a } \\
\text { constraint? }\end{array}$ & $\begin{array}{l}\text { Health Promotion } \\
\text { International }\end{array}$ & Cross-sectional & Qualitative & Primary data & 3 & & 1 & 4 \\
\hline 19 & $\begin{array}{l}\text { Indonesia } \\
\text { (LMIC) }\end{array}$ & No & 2010 & $L u, Y$ & $\begin{array}{l}\text { Mental health and risk behaviours of rural urban migrants: Longitudinal evidence } \\
\text { from Indonesia }\end{array}$ & Population Studies & $\begin{array}{l}\text { Longitudinal } \\
\text { (retrospective) }\end{array}$ & Quantitative & $\begin{array}{l}\text { Secondary } \\
\text { data }\end{array}$ & 3 & & 1 & 4 \\
\hline 20 & $\begin{array}{l}\text { Indonesia } \\
\text { (LMIC) }\end{array}$ & Yes & 2010 & $L u, Y$ & Rural-urban Migration and Health: evidence from longitudinal data in Indonesia & Social Science \& Medicine & $\begin{array}{l}\text { Longitudinal } \\
\text { (retrospective) }\end{array}$ & Quantitative & $\begin{array}{l}\text { Secondary } \\
\text { data }\end{array}$ & 3 & & 1 & 4 \\
\hline 21 & China (NIC) & No & 2010 & Wang et al & $\begin{array}{l}\text { The influence of social stigma and discriminatory experience on psychological } \\
\text { distress and quality of life among rural-to-urban migrants in China }\end{array}$ & Social Science \& Medicine & Cross-sectional & Quantitative & $\begin{array}{l}\text { Secondary } \\
\text { data }\end{array}$ & 3 & & 1 & 4 \\
\hline 22 & China (NIC) & No & 2012 & Chen et al & $\begin{array}{l}\text { Mental health, duration of unemployment, and coping strategy: a cross-sectional } \\
\text { study of unemployed migrant workers in eastern china during the economic crisis }\end{array}$ & Bmc Public Health & Cross-sectional & Quantitative & Primary data & 3 & & 1 & 4 \\
\hline 23 & China (NIC) & No & 2012 & Mao et al & $\begin{array}{l}\text { The effects of social connections on self-rated physical and mental health among } \\
\text { internal migrant and local adolescents in Shanghai, China }\end{array}$ & BMC Public Health & Cross-sectional & Quantitative & Primary data & 3 & & 1 & 4 \\
\hline 24 & China (NIC) & No & 2012 & Yang et al & $\begin{array}{l}\text { Mental health status and related characteristics of Chinese male rural-urban } \\
\text { migrant workers }\end{array}$ & Community Ment Health J & Cross-sectional & Quantitative & Primary data & 3 & & 1 & 4 \\
\hline 25 & China (NIC) & No & 2012 & Zhu et al & Correlates of quality of life in China rural-urban female migrate workers & Quality of Life Research & Cross-sectional & Quantitative & Primar & 3 & & 1 & 4 \\
\hline 26 & China (NIC) & No & 2013 & Chen et al & Migration, environmental hazards, and health outcomes in China & Social science \& medicine & Cross-sectional & Quantitative & $\begin{array}{l}\text { Secondary } \\
\text { data }\end{array}$ & 3 & & 1 & 4 \\
\hline 27 & China (NIC) & No & 2014 & Chen et al & How Dynamics of Urbanization Affect Physical and Mental Health in Urban China & China Quarterly & Cross-sectional & Quantitative & Primary data & 3 & & 1 & 4 \\
\hline
\end{tabular}




\begin{tabular}{|c|c|c|c|c|c|}
\hline & China (NIC) & Yes & 2014 & Cheung, $\mathrm{N}$ & $\begin{array}{l}\text { Social stress, locality of social ties and mental well-being: The case of rural migrant } \\
\text { adolescents in urban China }\end{array}$ \\
\hline & China (NIC) & No & 2014 & Li et al & $\begin{array}{l}\text { Mental wellbeing amongst younger and older migrant workers in comparison to } \\
\text { their urban counterparts in Guangzhou city, China: a cross-sectional study }\end{array}$ \\
\hline & China (NIC) & No & 2015 & Hoi et al & $\begin{array}{l}\text { The Association Between Social Resources and Depressive Symptoms Among } \\
\text { Chinese Migrants and Non-Migrants Living in Guangzhou, China }\end{array}$ \\
\hline & China (NIC) & No & 2015 & Liang, $Y$ & $\begin{array}{l}\text { Correlations Between Health-Related Quality of Life and Interpersonal Trust: } \\
\text { Comparisons Between Two Generations of Chinese Rural-to-Urban Migrants }\end{array}$ \\
\hline & $\begin{array}{l}\text { Sri Lanka } \\
\text { (LMIC) }\end{array}$ & Yes & 2015 & $\begin{array}{l}\text { Siriwardhan } \\
\text { a et al }\end{array}$ & $\begin{array}{l}\text { Dynamics of resilience in forced migration: a 1-year follow-up study of longitudinal } \\
\text { associations with mental health in a conflict-affected, ethnic Muslim population }\end{array}$ \\
\hline & China (NIC) & No & 2015 & Wuet al & $\begin{array}{l}\text { Social capital and the mental health of children in rural China with different } \\
\text { experiences of parental migration }\end{array}$ \\
\hline & $\begin{array}{l}\text { Vietnam } \\
\text { (LMIC) }\end{array}$ & No & 2015 & Yamada et al & $\begin{array}{l}\text { Living Arrangements and Psychological Well-Being of the Older Adults After the } \\
\text { Economic Transition in Vietnam }\end{array}$ \\
\hline & China (NIC) & No & 2015 & Zhang et al & $\begin{array}{l}\text { Internal migration and the health of the returned population: a nationally } \\
\text { representative study of China }\end{array}$ \\
\hline & China (NIC) & No & 2016 & Chen et al & $\begin{array}{l}\text { Online Information Searches and Help Seeking for Mental Health Problems in } \\
\text { Urban China }\end{array}$ \\
\hline & China (NIC) & No & 2016 & Chen et al & $\begin{array}{l}\text { The Physical and Psychological Health of Migrants in Guangzhou, China: How Does } \\
\text { Neighborhood Matter? }\end{array}$ \\
\hline 8 & China (NIC) & No & 2016 & $\mathrm{Ni}$ et al & $\begin{array}{l}\text { Subjective well-being amongst migrant children in China: unravelling the roles of } \\
\text { social support and identity integration }\end{array}$ \\
\hline & China (NIC) & No & 2016 & Song et al & $\begin{array}{l}\text { Health consequences of rural-to-urban migration: evidence from panel data in } \\
\text { China }\end{array}$ \\
\hline 40 & China (NIC) & Yes & 2016 & Ye et al & $\begin{array}{l}\text { Peer Victimization and Depressive Symptoms Among Rural-to-Urban Migrant } \\
\text { Children in China: The Protective Role of Resilience }\end{array}$ \\
\hline 11 & China (NIC) & $\begin{array}{c}\text { abstract } \\
\text { only }\end{array}$ & 016 & $\mathrm{Yi}_{\mathrm{i}}$ & $\begin{array}{l}\text { A improved statistical model analysis the mental health of rural-to-urban migrants } \\
\text { in China }\end{array}$ \\
\hline 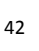 & $\begin{array}{l}\text { South Africa } \\
\text { (NIC) }\end{array}$ & No & 2017 & Ajaero et al & The influence of internal migration on mental health status in South Africa \\
\hline 43 & China (NIC) & No & 2017 & Cheng et al & $\begin{array}{l}\text { U-Shaped Relationship between Years of Residence and Negative Mental Health } \\
\text { Outcomes among Rural-to-Urban Children in Migrant Schools in Beijing, China }\end{array}$ \\
\hline & China (NIC) & No & 2017 & Guan & $\begin{array}{l}\text { Measuring the effects of socioeconomic factors on mental health among migrants } \\
\text { in urban China: A multiple indicators multiple causes model }\end{array}$ \\
\hline & China (NIC) & No & 2017 & Lin et al & $\begin{array}{l}\text { The social income inequality, social integration and health status of internal } \\
\text { migrants in China }\end{array}$ \\
\hline 16 & China (NIC) & No & 2017 & Wang et al & $\begin{array}{l}\text { Prevalence of mental health problems and associated risk factors among rural-to- } \\
\text { urban migrant children in Guangzhou, China }\end{array}$ \\
\hline & China (NIC) & No & 2017 & Wang et al & Psychological adjustment and behaviours in children of migrant workers in China \\
\hline 48 & China (NIC) & Yes & 2017 & Wen et al & $\begin{array}{l}\text { Psychological distress of rural-to-urban migrants in two Chinese cities: Shenzhen } \\
\text { and Shanghai }\end{array}$ \\
\hline 19 & China (NIC) & Yes & 2017 & Zhuang et al & $\begin{array}{l}\text { Differentiali impacts of social support on mental heaetth: A comparisson studd of } \\
\text { Chinese rural-to-urban migrant adolescents and their urban counterparts in } \\
\text { Beijing, China }\end{array}$ \\
\hline
\end{tabular}

Health \& Place

BMC Public Health

Journal of Pacific Rim

Psychology

Social Indicators Research

BMJ Open

social Science \& Medicine

ournals of Gerontology Series B-Psychological

BMC Public Health

Administration and Policy in Mental Health and Mental Health Servic
Research

nquiry : a journal of provision and financing Child Care Health Dev

Health Economics

Frontiers in Psychology International Journal of Smart Home

International Journal of Frontiers in Public Healt

International Journal of International Journal for Equity in Health

International Journal of and Public Health Child Care Health and Development

Asian Population Studies International Journal of Social Psychiatry 